\title{
Integration of field erosion measurements with erosion models and 3D civil design tools for development of erosion resistant cover systems
}

\author{
R Peroor SRK Consulting (US), Inc., USA \\ EJ Howard Landloch Pty Ltd, Australia \\ T Braun SRK Consulting (US), Inc., USA \\ T Chesal BHP Copper Inc., USA
}

S Chataut BHP Copper Inc., USA

\begin{abstract}
Post-closure maintenance activities for various inactive copper tailings impoundments owned by BHP in Arizona (USA) require frequent erosion-related inspections and repairs. BHP assessed these recurring costs and post-closure hazards and commissioned a study of alternative methods to design a more robust, erosionresistant solution. The study combined field erosion testing, 2D and 3D erosion models, and landform design tools in an innovative way that allowed BHP to make an informed decision regarding improvements to the erosional stability of the tailings impoundments.
\end{abstract}

The study started with field-based material testing. Simulated rainfall and overland flows were applied to 13 test surfaces representing different cover systems, and measurements of infiltration capacity, interrill and rill erodibility, flow shear stress, and sediment size and density distributions were made. The field measurements allowed calibration of parameters for the Water Erosion Prediction Project (WEPP) erosion model and SIBERIA landform evolution model for the different cover systems. The study team used the calibrated WEPP model to evaluate the erosion performance of linear and curvilinear embankment profiles and retained cover systems that met minimum erosion performance standards. The performance standards were established using data on the erosion of surrounding undisturbed vegetated hillslopes and a review of the published literature detailing erosion benchmarks for rangelands in southwestern USA.

The design team developed 3D surfaces of the linear and curvilinear slope profiles developed from WEPP modelling, and more complex $3 D$ surfaces developed from the GeoFluv ${ }^{T M}$ software. These surfaces were subjected to 3D landform evolution modelling using SIBERIA. Inputs to the SIBERIA model and GeoFluv ${ }^{T M}$ software were informed using data collected during the field studies. Each SIBERIA model iteration provided insight regarding short-term and long-term erosion performance for each 3D surface and cover system. The design team produced initial and sustaining capital cost estimates for the final engineering designs based on this output.

This paper details the innovative approach taken to integrate field measures of erodibility, 2D and 3D models, and civil 3D design software to produce defensible long-term closure designs that are material and site specific, and cost-effective.

Keywords: landform design, erosion covers, natural analogue

\section{Introduction}

BHP Copper Inc. (BHP) plans to permanently close various inactive mine operations at the Globe-Miami area of Arizona. Existing landforms include tailings facilities (embankment gradients of $50 \%$, slope lengths up to $200 \mathrm{~m}$ ), heap leach facilities (embankment gradients of 50\%, slope lengths up to $160 \mathrm{~m}$ ) and waste rock 
facilities (embankment gradients of 50\%, slope lengths up to $100 \mathrm{~m}$ ). Long-term performance of the cover system coupled with landform stability were identified as key determinants of closure success. For these landforms, closure designs are required that are more erosion-resistant and that reduce maintenance and monitoring requirements. Although reclamation practices are established and widely adopted throughout the mining industry in the USA, use of landform evolution erosion models to inform reclamation designs, such as SIBERIA, has not been common. Use of empirical models (those derived from observation and experiment) such as Revised Universal Soil Loss Equation (RUSLE) has been more common. Process-based models (those that use mathematical equations to describe the processes being modelled) such as the Water Erosion Prediction Project (WEPP) model have also been applied. Inclusion of landform evolution erosion models offers the opportunity for more detailed erosion assessments that in turn can inform cost considerations of various designs over long timescales.

As part of their closure planning, BHP initially reviewed existing closure criteria, as-built construction documentation, and the performance of reclaimed facilities at adjacent sites to gain an understanding of the types of closure designs that had been historically implemented. The types of cover systems and landform shapes were specifically considered. Erosion patterns, vegetation impacts, and measures of the frequency and magnitude of maintenance activities of the various cover systems were reviewed.

In response to this review, BHP commissioned a field-based erodibility study at an inactive mine in Miami (AZ) that occurred in March/April 2018 (Stage 1A) and July 2018 (Stage 1B). The objective was to collect sitespecific field data to calibrate erosion models and predict long-term erosion rates for different remediated landform shapes. Figure 1 presents the relationship between the field erodibility trials (Stages $1 \mathrm{~A}$ and 1B) and the subject of this paper, Stage 2. The results of Stage 2 will be used within long-term benchmarking studies in which the performance of the modelled designs will be assessed and used to validate the model against real world data (Stage 3).

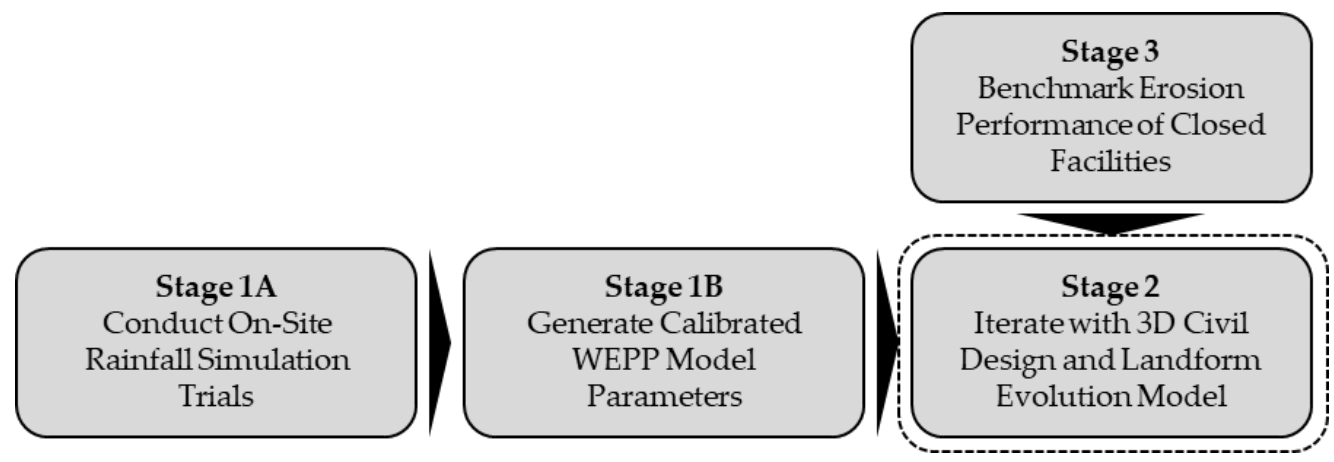

Figure 1 Erosion study phases (Braun et al. 2018)

\section{Erosion benchmarking}

When designing closure landforms, a way of demonstrating success is to show that the remediated landform will not be subject to excessive rates of erosion in the long-term. It is also important that design erosion rate thresholds are not set so low as to be unachievable and inconsistent with a surrounding landscape. Consequently, for this study, erosionally stable designs are governed by an acceptable or benchmark rate of erosion. A literature review of the published benchmark erosion rates relevant to rangelands in southwestern USA was performed. Table 1 presents a summary of the erosion benchmark review.

Based on the results of the benchmarking exercise, the long-term erosion rate of $6 \mathrm{t} / \mathrm{ha}$ p.a. was established as the benchmark for screening different cover and landform options. Design options that exceeded this threshold was classified as unacceptable. 
Table $1 \quad$ Summary of erosion benchmark review

\begin{tabular}{|c|c|c|c|}
\hline Description & Source & $\begin{array}{c}\text { Erosion } \\
\text { benchmark } \\
\text { (t/ha p.a.) }\end{array}$ & Comment \\
\hline $\begin{array}{l}\text { Historical thresholds (USA } \\
\text { rangelands) }\end{array}$ & $\begin{array}{l}\text { Browning et al. (1947) } \\
\text { McCormack et al. (1982) }\end{array}$ & 5 & - \\
\hline $\begin{array}{l}\text { Rates that promote rilling } \\
\text { and gullying }\end{array}$ & $\begin{array}{l}\text { Klingebiel (1961) } \\
\text { Loch and Donnollan (1983) }\end{array}$ & $\begin{array}{c}11 \\
3\end{array}$ & - \\
\hline Rates to maintain soil depth & USDA-NRCS (1999) & $\begin{array}{l}5 \\
8\end{array}$ & $\begin{array}{l}25-50 \mathrm{~cm} \text { soil depth } \\
50-100 \mathrm{~cm} \text { soil depth }\end{array}$ \\
\hline $\begin{array}{l}\text { Published erosion rates for } \\
\text { Arizona rangelands }\end{array}$ & USDA (1981) & $\begin{array}{c}5 \\
12\end{array}$ & $\begin{array}{l}73 \% \text { of rangelands }<5 \\
88 \% \text { of rangelands }<12\end{array}$ \\
\hline WEPP erosion prediction & $\begin{array}{l}\text { Slope gradients ranging } \\
\text { from } 20-66 \% \text { and slope } \\
\text { lengths ranging from } \\
200-300 \mathrm{~m}\end{array}$ & $5-6$ & $\begin{array}{l}\text { Varies with slope length, } \\
\text { gradient and shape }\end{array}$ \\
\hline
\end{tabular}

\section{Landform design approach}

The landform design approach involves developing a landform condition that considers site-specific material characteristics, long-term climate conditions, vegetation and topographic relief. To assess whether landforms meet the erosion performance standards the workflow shown in Figure 2 was developed. Potentially erosionresistant cover options were identified during an initial review of the performance of cover systems associated with reclaimed facilities at adjacent mine sites. Test plots of the different cover systems identified were then constructed, and rapid onsite rainfall and overland flow simulations were conducted on the plots. The field data collected were used to generate material-specific Water Erosion Prediction Project (WEPP) (Flanagan \& Livingston 1995) erodibility parameters. An iterative process incorporating 3D landform (civil) design software and erosion models was used to assess erosional stability of each landform design and the relationship between long-term erosional performance and cost. The outcome of this iterative process was the identification of designs that achieved the required erosion performance standards while maintaining a suitable initial and sustaining capital cost.

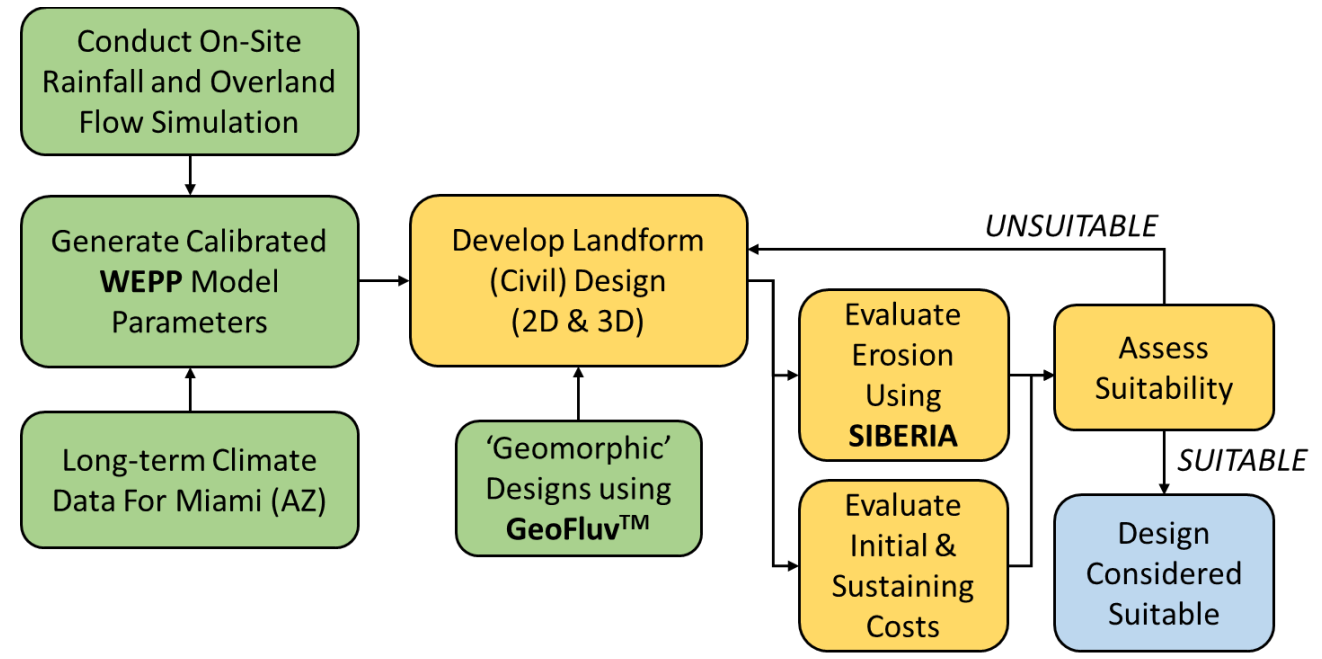

Figure 2 Landform design approach workflow 


\subsection{Onsite erodibility studies}

Onsite erodibility studies were conducted to test the potential cover materials and analyse their performance as an effective erosion-resistant system. Field erodibility studies were also conducted on undisturbed natural terrain to use that as a benchmark against which various cover systems were analysed.

\subsubsection{Site geology and borrow material characterisation}

The geology of the Globe-Miami area is dominated by tertiary-aged Gila Conglomerate (Gila). Gila has been used extensively as a soil cover for reclamation of several mine facilities in Arizona. The Gila Group is a basin-fill formation noted in numerous localities in central Arizona dominantly composed of overlapping alluvial fans of material derived from the rocks of the nearest mountain range - in this case the Pinal Mountains.

Gila is a boulder conglomerate, interbedded with layers of slightly coherent sand, tuff, and sheets of basalt. Gila can be classified as silty sand with gravel (SM) based on Unified Soil Classification System (USCS). The particle size distribution of Gila is variable with gravel content ranging between 20 to $45 \%$ by weight, sand content between 45 to $70 \%$ and fines content (passing \#200 US sieve) varying between 10 to $20 \%$ by weight. Gila can be screened to generate a rock armour material with mean diameter $\left(D_{50}\right)$ of 25 to $50 \mathrm{~mm}$. Larger size rock armours can be generated from nearby limestone quarries. Rock generated from Gila are subrounded to sub-angular in shape and larger size rock generated from limestone quarries are sub-angular to angular in shape.

\subsubsection{Phase I erosion testing}

Eight field plots (Plots 1-9) with different surface treatments were tested during a field campaign from 26 March to 5 April 2018. Plot 1 represented an undisturbed 'vegetated' natural Gila hillslope. Plots 2 through 8 represented various potential cover systems considered for the closure design based on the initial review of cover systems used on the surrounding mines. Each of these surfaces was placed over $\sim 0.6 \mathrm{~m}$ of run of borrow Gila layer. Plot 8 represented a Gila layer without any rock armour and vegetation. This represented a post construction scenario prior to establishment of vegetation. Plots 2, 3, 4 and 9 represented rock armour surfaces of different mean diameters. Plots 6 and 7 contained a veneer of coarse Gila screenings overlying the screened fines (Plot 6) and a mixture of the screen fines and run of borrow Gila (Plot 7). Plot 5 was constructed with the same surface as Plot 9 but with a lower gradient (33\%). Given that adequate data was able to be recorded from Plot 9 alone, Plot 5 was not tested. Gila for the entire testing campaign was borrowed from a common source.

The material was placed in $0.15 \mathrm{~m}$ lifts and was compacted by tracking the dozer up and down the slope (four passes). The lift thickness and compaction effort using the dozer was kept consistent for all the field plots. Multiple wetting and drying cycles (four to five) were applied to each plot to assist with consolidation of the surface and initiation of the surface armouring process. The rainfall simulator used is similar to that described by Loch et al. (2001). Simulated rain was applied to triplicate plots and timed sediment samples taken. Samples used for characterising the eroded sediment were taken from the rain wet plots once the rainfall had ceased. Overland flows were then applied to the same rain wet surfaces and sediment samples taken along with measurements of the rill flow. WEPP parameters associated with the different surface treatments were derived from the field data and described in detail by Braun et al. (2018). 


\subsubsection{Phase II erosion testing}

Based on the review of the Phase I test results, a second phase (Phase II) of testing was completed to further assess the results of the best performing cover system (Plot 2) as well as to test various other cost-effective cover system options. Testing was performed between 19 July to 31 July 2018. Two additional options were considered:

- Quarry rock (rock armour procured externally) mixed with run of borrow Gila to increase its coarse content and potential to resist erosion.

- Addition of a filter/bedding layer below the rock and above the underlying run of borrow Gila.

Plot $2 \mathrm{~A}$ had the same configuration as Plot 2 and was run a second time as a check of the results for this plot run during the first campaign. Plot $4 A$ and $3 A$ use run of borrow Gila mixed with $D_{50} 25-75 \mathrm{~mm}$ rock and $D_{50} 75-150 \mathrm{~mm}$ rock respectively at a ratio of 1:1 by weight. These plots are designed to consider whether mixing additional rock into the run of borrow Gila yields different results than placement of the rock over the Gila as a veneer. These plots reduce the amount of required imported rock armour by half resulting in significant cost reduction. Plots $5 \mathrm{~A}$ and $8 \mathrm{~A}$ involved placement of a filter layer ( $12.5 \mathrm{~mm}$ diameter rock) under the $D_{50} 25-75 \mathrm{~mm}$ rock and $D_{50} 75-150 \mathrm{~mm}$ rock armour respectively. The filter layer was designed based on the rock slope protection guidelines from US Department of the Interior Bureau of Reclamation (2014).

The same testing equipment and techniques as described in the Phase I testing was applied in Phase II. Select images of the field study are shown in Figure 3. Table 2 presents a summary of surface treatments tested as part of the Phase I and II campaigns. The plot descriptions for Phase II are differentiated by the addition of the suffix ' $A$ ' after the plot number.
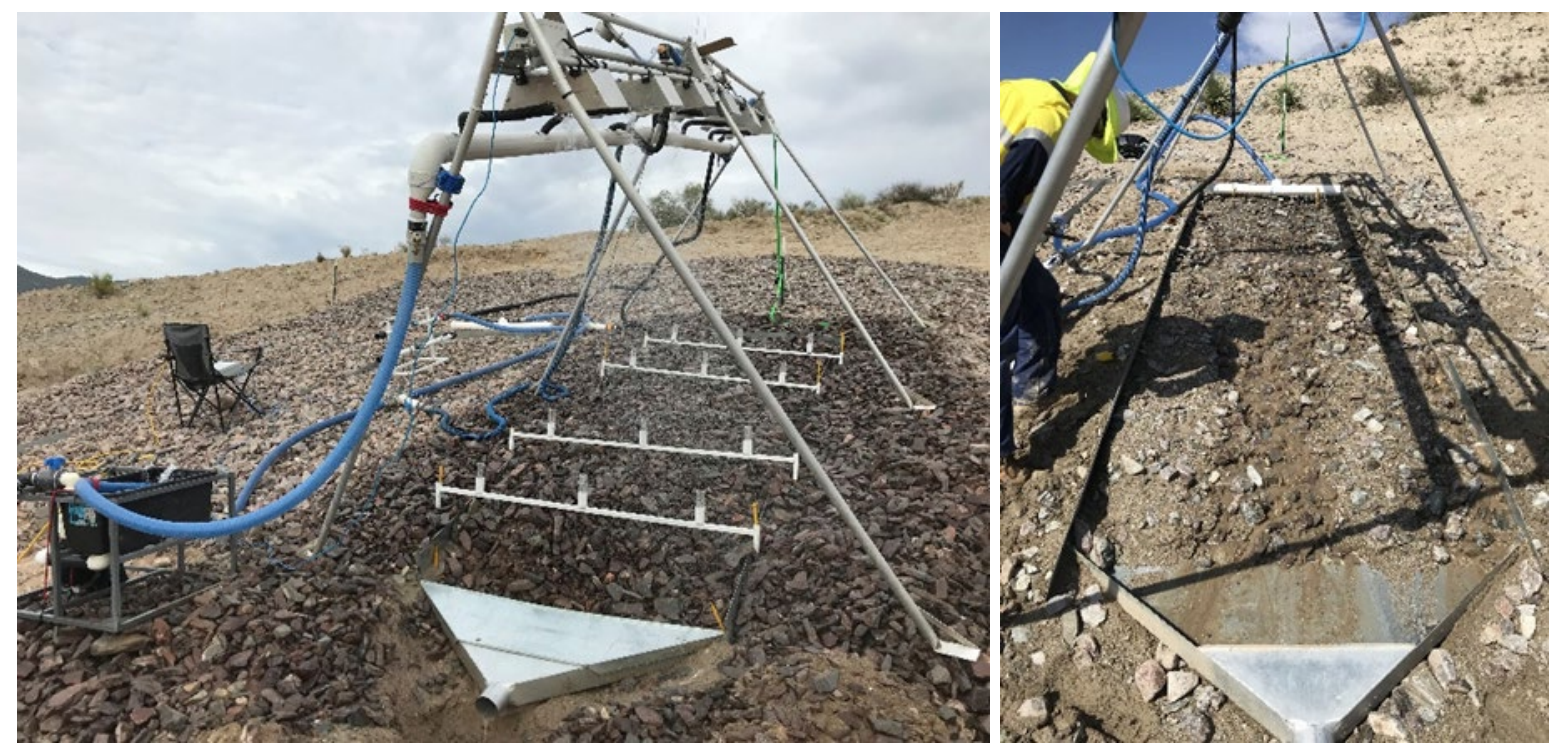

Figure 3 Rainfall and overland flow simulations: (left) Plot 5A/8A rainfall simulations; (right) Plot 3A/4A overland flow simulations 
Table 2 Surfaces tested during the field-based erodibility study

\begin{tabular}{|c|c|c|}
\hline \multirow{2}{*}{ Plot } & \multicolumn{2}{|r|}{ Surface treatments } \\
\hline & Bottom layer & Top layer(s) \\
\hline 1 & \multicolumn{2}{|c|}{ Natural Gila hillslope (benchmark to compare the performance of different surface treatments) } \\
\hline 2 & $600 \mathrm{~mm}$ run of borrow Gila & $300 \mathrm{~mm}$ imported rock armour $\left(D_{50}=25-75 \mathrm{~mm}\right)$ \\
\hline 3 & $600 \mathrm{~mm}$ run of borrow Gila & $300 \mathrm{~mm}$ imported rock armour $\left(D_{50}=75-150 \mathrm{~mm}\right)$ \\
\hline 4 & $600 \mathrm{~mm}$ run of borrow Gila & $300 \mathrm{~mm}$ imported rock cover $\left(D_{50}=150 \mathrm{~mm}\right)$ \\
\hline 6 & $600 \mathrm{~mm}$ of the screened Gila fines & $300 \mathrm{~mm}$ screened run of borrow Gila $\left(D_{50}=35 \mathrm{~mm}\right)$ \\
\hline 7 & $\begin{array}{l}600 \mathrm{~mm} \text { of screened Gila fines mixed } \\
\text { with run of borrow Gila }\end{array}$ & $300 \mathrm{~mm}$ screened run of borrow Gila $\left(D_{50}=35 \mathrm{~mm}\right)$ \\
\hline 8 & \multicolumn{2}{|c|}{$900 \mathrm{~mm}$ run of borrow Gila (represents post-construction 'no vegetation' condition } \\
\hline 9 & $600 \mathrm{~mm}$ run of borrow Gila & $450 \mathrm{~mm}$ imported rock armour $\left(D_{50}=200 \mathrm{~mm}\right)$ \\
\hline $2 \mathrm{~A}$ & $600 \mathrm{~mm}$ run of borrow Gila & $300 \mathrm{~mm}$ imported rock armour $\left(D_{50}=25-75 \mathrm{~mm}\right)$ \\
\hline $3 \mathrm{~A}$ & $600 \mathrm{~mm}$ run of borrow Gila & $\begin{array}{l}300 \mathrm{~mm} \text { run of borrow Gila mixed with imported rock } \\
\text { armour }\left(D_{50}=75-150 \mathrm{~mm}\right) \text { in 1:1 ratio by weight }\end{array}$ \\
\hline $4 \mathrm{~A}$ & $600 \mathrm{~mm}$ run of borrow Gila & $\begin{array}{l}300 \mathrm{~mm} \text { run of borrow Gila mixed with imported rock } \\
\text { armour }\left(D_{50}=25-75 \mathrm{~mm}\right) \text { overlying by weight }\end{array}$ \\
\hline $5 A$ & $600 \mathrm{~mm}$ run of borrow Gila & $\begin{array}{l}300 \mathrm{~mm} \text { imported rock armour }\left(D_{50}=25-75 \mathrm{~mm}\right) \text { overlying } \\
300 \mathrm{~mm} \text { imported filter layer }\left(D_{50}=12.5 \mathrm{~mm}\right)\end{array}$ \\
\hline $8 \mathrm{~A}$ & $600 \mathrm{~mm}$ run of borrow Gila & $\begin{array}{l}300 \mathrm{~mm} \text { imported rock armour }\left(D_{50}=75-150 \mathrm{~mm}\right) \\
\text { overlying } 300 \mathrm{~mm} \text { imported filter layer }\left(D_{50}=12.5 \mathrm{~mm}\right)\end{array}$ \\
\hline
\end{tabular}

\subsection{Initial erosion modelling and calibration}

Existing landforms at various inactive mine operations at Globe-Miami area of Arizona will need to be re-sloped and covered with an erosion resistant cover system to meet the permanent closure objective of maintaining a stable landform condition. Vegetation re-establishment is not a regulatory requirement.

Empirical erosion models such as RUSLE (Renard et al. 1993) offer a simple means of assessing erosion on an annual basis. However, these models do not consider temporal variations in runoff or erosion potential, explicitly consider erosion resulting from rills, or readily provide predictions of changing erosion rates along a slope length, giving only a total erosion rate from the slope. In comparison, a process-based model such as WEPP operates on a daily time step, provides erosion predictions on an event basis (rather than annual rates only), predicts erosion changes along a slope length, and can account for erosion in rills. Howard et al. (2013) provides a comparison of the RUSLE and WEPP models and how they can be used in mine site closure designs. The WEPP model was used to predict runoff and erosion based on the calibrated erodibility parameters derived from the field tests. All WEPP simulations used a 100-year climate file developed using parameters from the US Department of Agriculture for Miami, AZ. Calibration against existing erosion could not be done as comparable slopes against which to assess the model outputs do not exist for all test surfaces. That said, erosion predictions were able to be ground-truthed by comparing long-term erosion predictions for the undisturbed plot (Plot 1) against reported benchmark data (Table 1) that included measured long-term erosion rates for conglomerate hillslopes in Arizona. 
The results for the Plot 2 surface also compared well against similar rock veneer surfaces present at an adjacent site. The adjacent site had been covered since 2007, little to no rill erosion had been observed. In addition, the methods described above have been shown to produce model parameters capable for predicting erosion quite accurately (Howard 2018). Further calibration of the model results will be performed for selected cover systems as part of Stage 3 of the project (Figure 1).

\subsubsection{Cover screening}

The WEPP model was used to predict long-term erosion of different test cover surfaces for a commonly occurring slope length of $300 \mathrm{~m}$ with a linear gradient of 18.4 degrees (33.3\%). The WEPP results are shown in Table 3.

Table 3 Water Erosion Prediction Project (WEPP) erosion prediction for a slope length of $300 \mathrm{~m}$ and $33 \%$ gradient

\begin{tabular}{|c|c|c|c|}
\hline \multirow[t]{2}{*}{ Plot } & \multirow[t]{2}{*}{ Description } & \multicolumn{2}{|c|}{$\begin{array}{l}\text { Average annual } \\
\text { erosion ( } t / \text { ha p.a. }\end{array}$} \\
\hline & & Mean & Peak \\
\hline 1 & Undisturbed Gila & 3.0 & 8.6 \\
\hline $2 / 2 \mathrm{~A}$ & $\mathrm{D}_{50} 25-75 \mathrm{~mm}$ over Gila & 4.4 & 11 \\
\hline 3 & $\mathrm{D}_{50} 75-150 \mathrm{~mm}$ over Gila & 16 & 44 \\
\hline 4 & $\mathrm{D}_{50,} 150 \mathrm{~mm}$ over Gila & 15 & 44 \\
\hline 9 & $\mathrm{D}_{50,} 200 \mathrm{~mm}$ over Gila & 32 & 87 \\
\hline 6 & Screened Gila rock over screened Gila fines & 3.6 & 9.3 \\
\hline 7 & Screened Gila rock over screened Gila fines mixed into Gila & 9.0 & 24 \\
\hline 8 & Run of borrow Gila & 29 & 44 \\
\hline $3 \mathrm{~A}$ & Gila mixed with $D_{50} 75-150 \mathrm{~mm}$ over Gila & 5.8 & 12 \\
\hline $4 \mathrm{~A}$ & Gila mixed with $D_{50} 25-75 \mathrm{~mm}$ over Gila & 9.8 & 25 \\
\hline $5 A$ & $D_{50} 25-75 \mathrm{~mm}$ over $D_{50} 12.5 \mathrm{~mm}$ filter layer over Gila & 0.6 & 1.2 \\
\hline $8 \mathrm{~A}$ & $\mathrm{D}_{50} 75-150 \mathrm{~mm}$ over $\mathrm{D}_{50} 12.5 \mathrm{~mm}$ filter layer over Gila & 1.2 & 2.9 \\
\hline
\end{tabular}

The undisturbed Gila hillslope (Plot 1 ) is predicted to erode at relatively low rates consistent with a slope that is not prone to rill and gully erosion. In contrast, the run of borrow Gila (Plot 8) which represents postconstruction condition with little to no vegetation is predicted to erode at much higher rates. This indicates that without application of an erosion resistant cover, reclaimed slopes are likely to be prone to rill and gully erosion. Use of screened Gila without mixing of the screened fines into the underlying run of borrow Gila (Plot6) is predicted to erode at rates similar to those predicted for the Plot 6 . This surface is predicted to be not prone to significant rill or gully erosion. Plot $2 / 2 A\left(D_{50} 25-75 \mathrm{~mm}\right)$ is predicted to erode at low rates similar to Plot 6 . These surfaces have similar $D_{50}$ values for the armour layer. Plots 3 and 4 are predicted to erode at higher rates compared to Plot 2. The higher erosion predictions are due to larger particle size of the rock armour layer resulting in greater flow turbulence within the layer causing greater detachment of the underlying run of borrow Gila. Plot 9 ( $D_{50}, 200 \mathrm{~mm}$ rock armour) is predicted to erode at higher rates than those predicted for the smaller rock armours. This is primarily due to higher predicted runoff rates.

Incorporation of additional rock into the run of borrow Gila (Plots $3 A$ and $4 A$ ) is predicted to reduce the erosion potential of the runoff borrow Gila (Plot 8$)$. When the larger rock is added (3-6' rock, Plot $3 A$ ) the erosion potential is reduced to that similar to Plot $2 / 2 \mathrm{~A}$. The surface with the incorporated rock may be advantageous for plant growth given the surface contains significantly higher plant available water than 
exists for the rock veneer option. Use of a filter layer under the rock armour layers (Plots 5A and 8A) are predicted to reduce erosion more than when only the rock armour is applied (Plots $2 / 2 \mathrm{~A}$ and 3 ). However, the Plot $2 / 2 \mathrm{~A}$ surfaces are predicted to erode at sufficiently low rates that rill erosion risk is minimised. Adoption of the more complex filter layers may be unnecessary for the linear slopes considered.

The cover materials used in Plots 2/2A, 3A, 5A and 6 met the erosion benchmark criteria and were retained. Plot $8 \mathrm{~A}$ was not retained even through it met the erosion benchmark because of its higher capital cost when compared to Plot $5 \mathrm{~A}$.

\subsubsection{Landform screening}

Linear slope designs have been the most popular post-mining reclaimed landforms due to their simplicity in design and construction. However, the long-term performance of slopes is often overlooked. Over a range of slopes and climates, the naturally occurring concave slopes have demonstrated a two to three-fold sediment reduction when compared to corresponding linear slopes (Priyashantha et al. 2009). For this study, WEPP model was used to predict relative erosion rates associated with four different landforms: linear, concave, convex-concave and convex profiles using the selected (best performing) cover systems. The results are summarised in Figure 4.

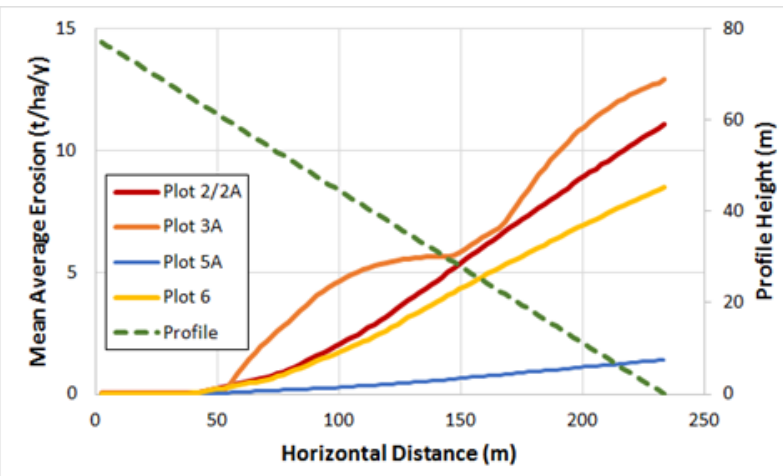

Linear slope erosion rates

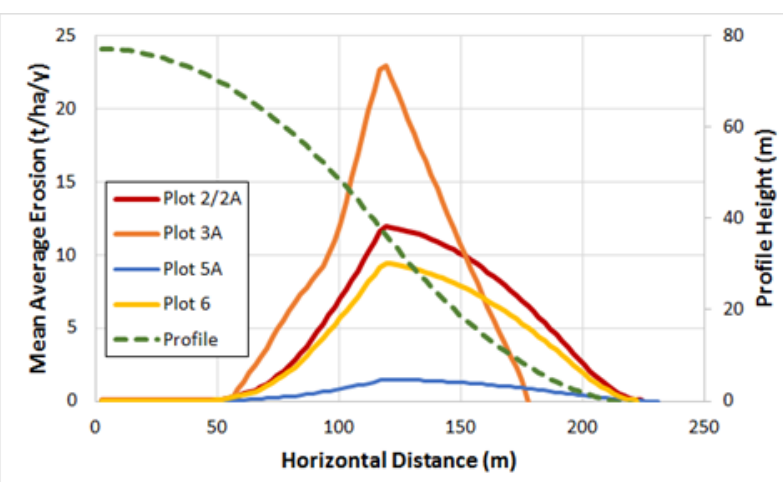

Convex-concave erosion rates

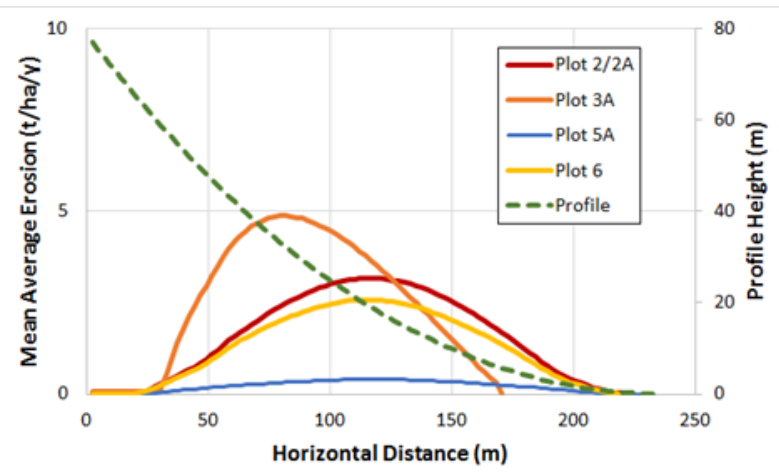

Concave slope erosion rates

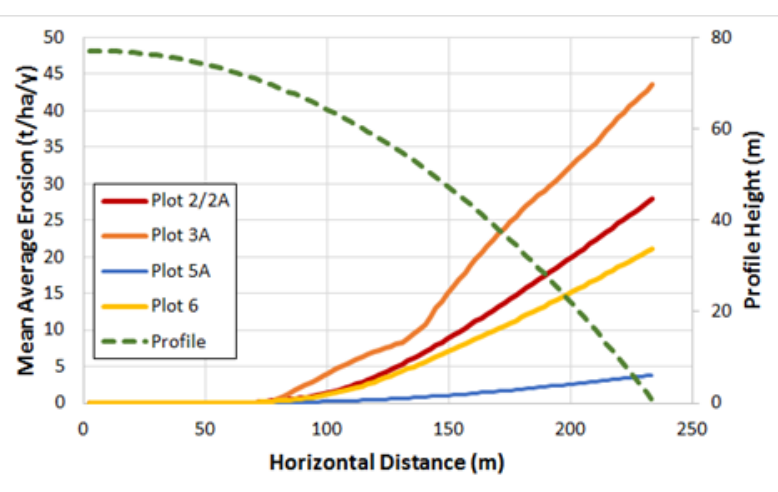

Convex slope erosion rates

Figure 4 Predicted erosion rates associated with different landforms

All cover systems are predicted to maintain low erosion rates for the initial $50 \mathrm{~m}$ of slope length. This slope length is required to enable sufficient accumulation of runoff and increase inflow shear stress to exceed the critical shear at which rill erosion is initiated. The erosion rates for slope lengths greater than $50 \mathrm{~m}$ is controlled by the rill erodibility values and to a lesser degree the interrill erodibility value. Erosion rates were observed to be sensitive to slope lengths, gradients and landform shapes. For cover system Plot 2/2A, predicted erosion rate was the lowest for the concave landform (1.6 t/ha p.a.) and highest for the convex landform (7.7 t/ha p.a.). The linear and convex concave landforms demonstrated similar erosion rates of $4.1 \mathrm{t} / \mathrm{ha}$ p.a. and $4.6 \mathrm{t} / \mathrm{ha}$ p.a. respectively. Similar erosion trends were observed for the cover systems $3 \mathrm{~A}$, $5 \mathrm{~A}$ and 6 as well. Cover system $5 \mathrm{~A}$ was the best performing surface treatment for the all the landforms. 


\subsection{D landform design development}

\subsubsection{Designs developed from 2D erosion model output}

Based on the results of the predictive WEPP analyses presented in Figure 4, linear, concave and convexconvex profiles were retained for 3D landform design development. Convex profile was not retained as it demonstrated significantly higher erosion rate with increasing horizontal distance for cover systems $2 / 2 \mathrm{~A}$, $3 A$ and 6 when compared to other slope profiles. Autodesk Civil 3D software was used to generate 3D triangular irregular network (TIN) surfaces based on the 2D slope profiles.

\subsubsection{Geomorphology-based design}

In addition to the designs developed from 2D erosion model output, other designs that incorporated a geomorphological aspect as well at the erosion modelling results were also developed. The intent of the geomorphology-based design is to construct stable landforms that more readily blend in with the surrounding natural landscape. In nature, hillslopes in the vicinity of the TSF have an upper convex and a lower concave profile. However, the degree of convexity and concavity varies across the surrounding area. The geomorphology-based design involved a desktop study of the natural terrain surrounding the tailings facility. The tailings facility has a maximum height of $80 \mathrm{~m}$. The embankment has an average gradient of $2 \mathrm{H}: 1 \mathrm{~V}$ (26.6 degrees) with multiple benches and interbench slope angles of 33 degrees. The approximate length of the reclaimed tailings embankment is $300 \mathrm{~m}$.

Mining landform design which adheres to the principles of geomorphology aims to consider both the natural landscape shapes and the drainage patterns of the surrounding area, while also ensuring that material limitations are not exceeded and that the resultant shapes do not embody unacceptable risks of failure. The design team reviewed the sectional profiles of several surrounding hillslopes as shown in Figure 5 and concluded that the extent of the convexity for most of the profiles was limited to $10-15 \%$ of the total hillslope length. However, the extent of concavity varies significantly throughout the hillslopes tested. Profile 4 shown in Figure 5 demonstrates the longest extent of the concavity and Profile 3 shows the shortest extent. These landforms were then inputted to the Autodesk Civil 3D to develop 3D TIN surfaces. The desktop study of the surrounding landscapes by the design team also reviewed the surrounding hill slope aspects and drainage densities. A hillslope area analogous to the tailings embankment slope was identified to the southeast of the facility as shown in Figure 6.

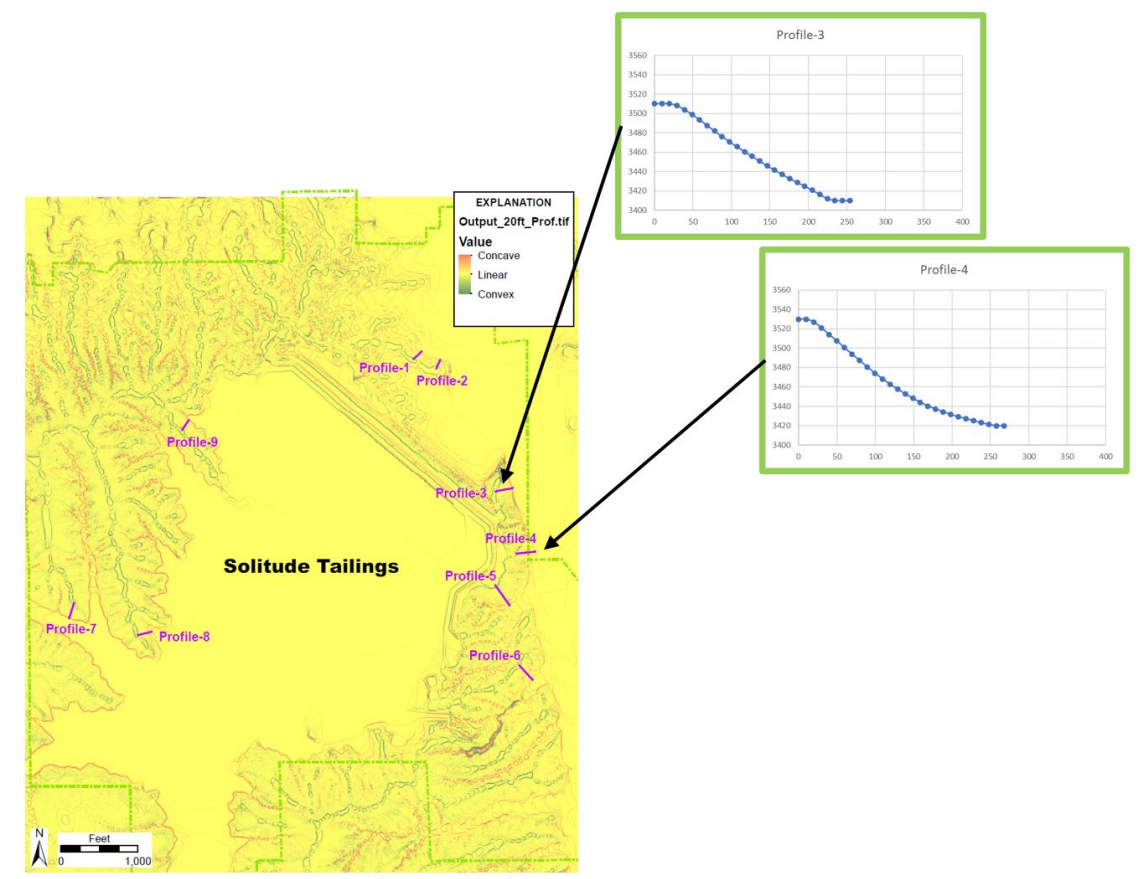

Figure 5 Desktop study of the natural landscapes surrounding tailings facility 


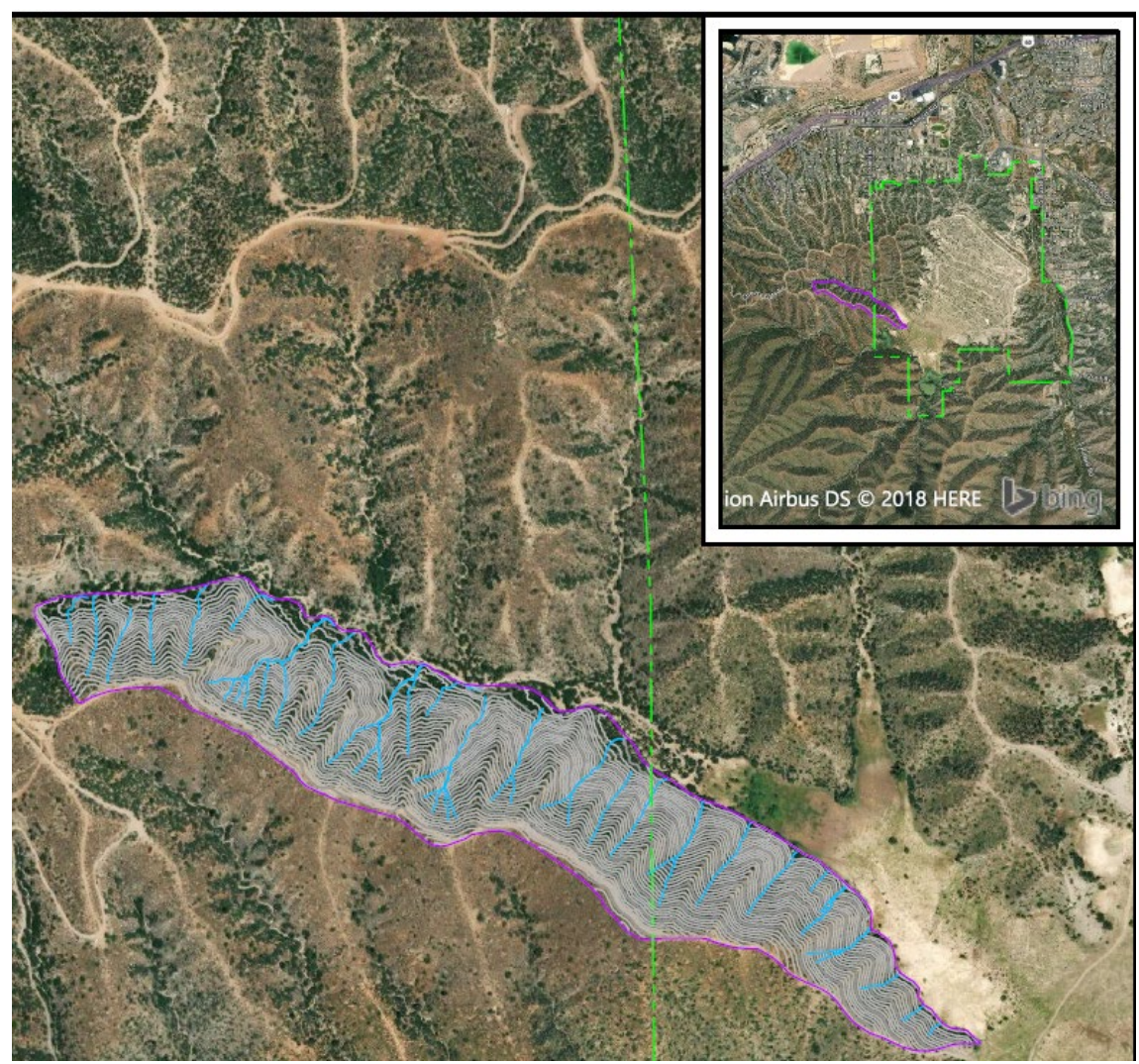

Figure 6 Desktop study of the natural landscapes surrounding tailings facility

Natural Regrade software (GeoFluv ${ }^{\mathrm{TM}}$ ) was used develop an embankment landform analogous to the hillslope area show in in Figure 6. The software uses drainage density as well as the extent of convexity and concavity to develop natural analogue based 3D landforms. The 3D landforms generated from the Natural regrade software was refined using the Autodesk Civil 3D. Figure 7 presents the 3D view of a range of landforms generated using Civil 3D and/or Natural Regrade.

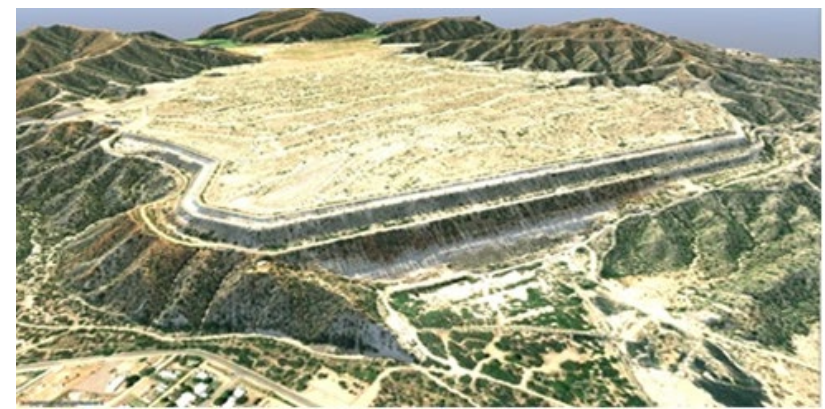

Existing condition

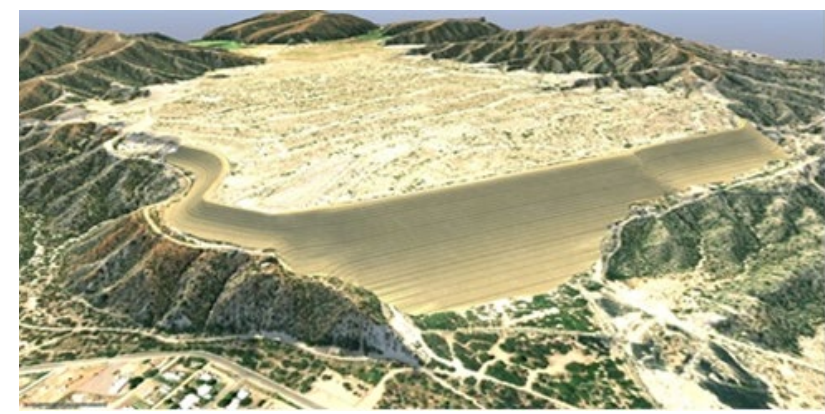

L4 convex-concave (3H:1V)

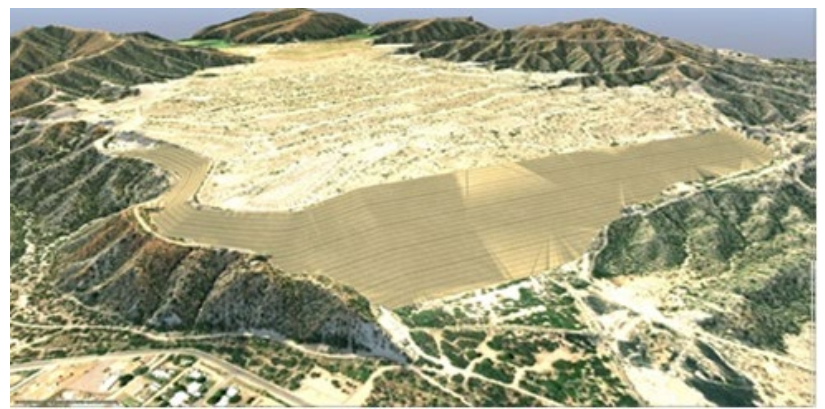

L1 straight slope (3H:1V)

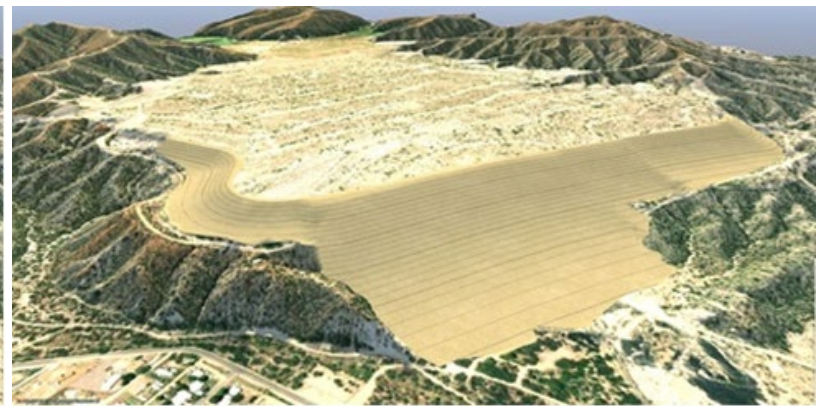

L5 convex-concave (4H:1V) 


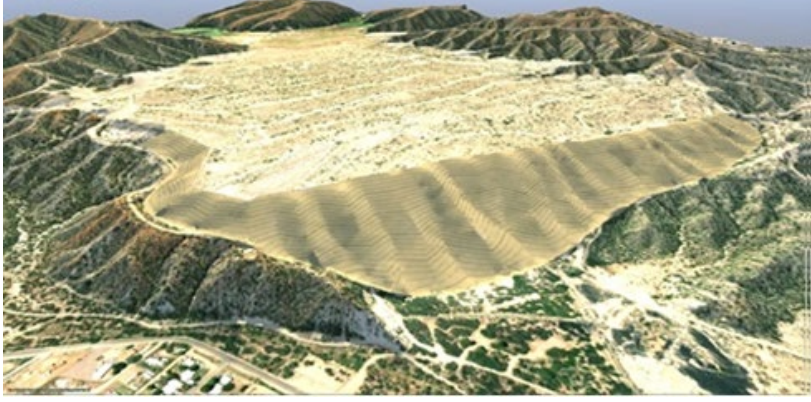

L8 natural drainage design- GeoFluv ${ }^{\mathrm{TM}}(3 \mathrm{H}: 1 \mathrm{~V})$

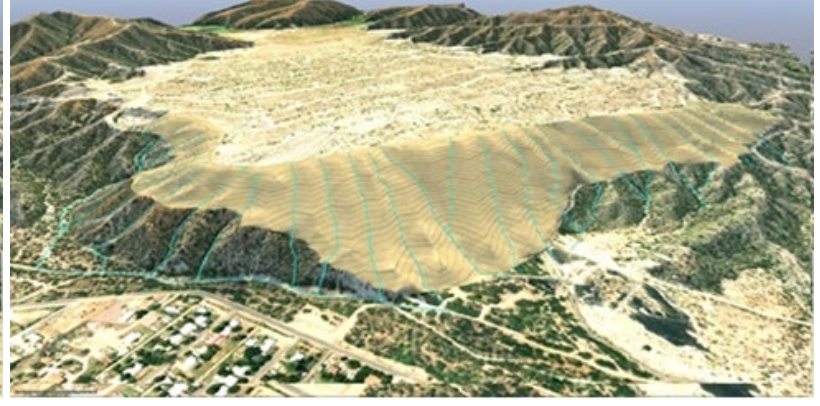

L9 natural drainage design- GeoFluv ${ }^{\mathrm{TM}}(4 \mathrm{H}: 1 \mathrm{~V})$

Figure 7 3D landform view of the tailings facility - Miami Globe

\subsection{Landform evolution modelling}

Landform evolution models predict both sediment yield and the rate of lowering of every point in the landscape as a function of time. They are sensitive to variation in slope within the landscape and the sediment yield at each time step is used to dynamically evolve the topography. The SIBERIA landform evolution model has been used extensively for the erosion assessment of post-mining landforms (Hancock et al. 2008; Willgoose \& Riley 1998). SIBERIA is a numerical model that solves the partial differential equations that quantify the transport of sediment through a landscape and the erosion and deposition that result from that sediment transport. It represents sediment transport by colluvial processes (creep and rain splash), overland flow, and channel flow. A key defining characteristic of SIBERIA is that it requires site-specific input data for how runoff relates to rainfall, drainage area and slope, and how sediment yield relates to runoff and slope. This approach leads to a more empirical model compared to other topographic evolution models.

SIBERIA was used for the long-term (100 year) erosion assessment of tailings facility landforms L1 (straight slope 3H:1V), L4 (convex-concave 3H:1V), L5 (convex-concave 4H:1V), L8 (natural drainage analogue 3H:1V), and $\mathrm{L9}$ (natural drainage analogue $4 \mathrm{H}: 1 \mathrm{~V}$ ). All the landforms were simulated for the cover systems $2 / 2 \mathrm{~A}$ ( $D_{50} 25-75 \mathrm{~mm}$ over Gila), 3A (Gila mixed with $D_{50} 75-150 \mathrm{~mm}$ over Gila), 5A ( $D_{50} 25-75 \mathrm{~mm}$ over $D_{50} 12.5 \mathrm{~mm}$ filter layer over Gila), and 6 (screened Gila rock over screened Gila fines). Table 4 provides a summary of mean erosion rates associated with different landform and different cover systems. Figure 8 presents an example of the 100-year landform evolution output (using the 2/2A cover system).

Table 4 SIBERIA erosion prediction - 100-year simulation

\begin{tabular}{|c|c|c|c|c|}
\hline \multirow[b]{2}{*}{ Landform } & \multicolumn{4}{|c|}{ Average erosion rate (t/ha p.a.) } \\
\hline & $\begin{array}{c}2 / 2 A \\
\left(D_{50} 25-75 \mathrm{~mm}\right. \\
\text { over Gila) }\end{array}$ & $\begin{array}{c}3 A \\
\text { (Gila mixed } \\
\text { with } D_{50} \\
75-150 \mathrm{~mm} \\
\text { over Gila) }\end{array}$ & $\begin{array}{c}5 A \\
\left(D_{50} 25-75 \mathrm{~mm}\right. \\
\text { over } D_{50} \\
12.5 \mathrm{~mm} \text { filter } \\
\text { layer over Gila) }\end{array}$ & $\begin{array}{c}6 \\
\text { (Screened Gila } \\
\text { rock over } \\
\text { screened Gila } \\
\text { fines) }\end{array}$ \\
\hline L1 (3H:1V straight slope) & 2.6 & 6.9 & 0.9 & 3.1 \\
\hline L4 (3H:1V convex-concave) & 1.9 & 3.2 & 0.5 & 1.9 \\
\hline L5 (4H:1V convex-concave) & 1.3 & 2.3 & 0.3 & 1.2 \\
\hline L8 (3H:1V natural analogue) & 9.9 & 13.3 & 2.8 & 8.8 \\
\hline L9 (4H:1V natural analogue) & 7.2 & 10.2 & 2.9 & 6.7 \\
\hline
\end{tabular}




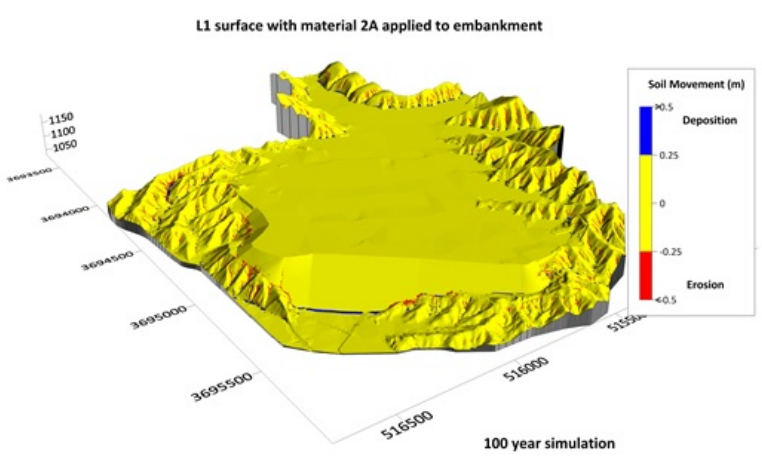

L1 straight slope (3H:1V)

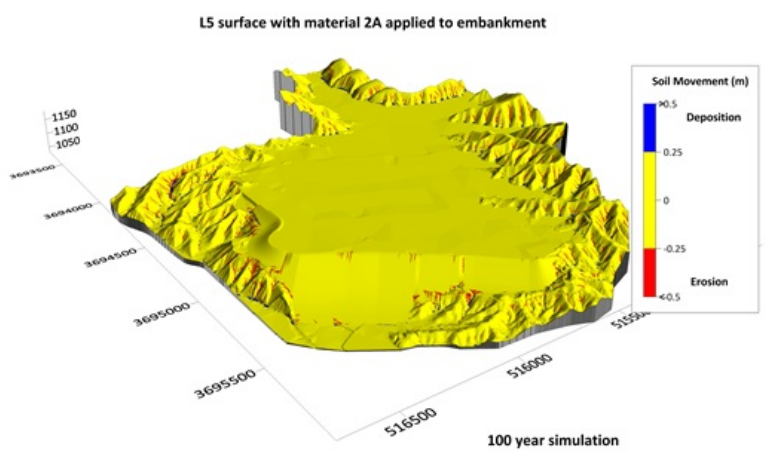

L5 convex-concave $(5 \mathrm{H}: 1 \mathrm{~V})$

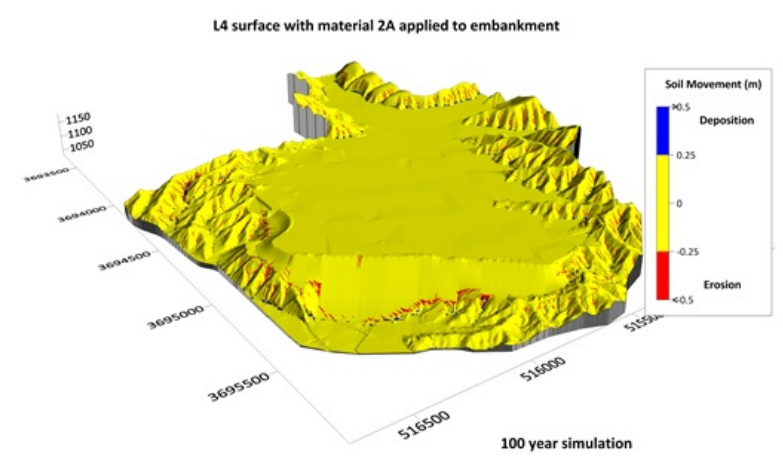

L4 convex-concave (3H:1V)

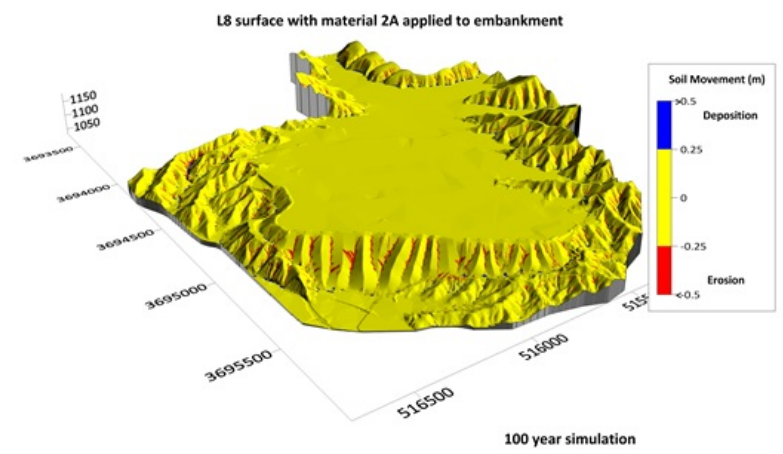

L8 natural drainage design - GeoFluv ${ }^{\mathrm{TM}}(3 \mathrm{H}: 1 \mathrm{~V})$

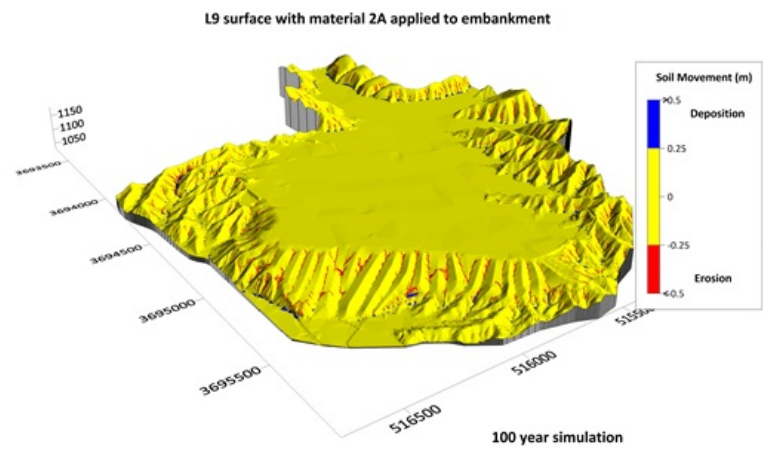

L9 natural drainage design - GeoFluv ${ }^{\mathrm{TM}}(4 \mathrm{H}: 1 \mathrm{~V})$

Figure 8 SIBERIA Results - 100 year simulation (Plot 2/2A cover system)

For all the simulated cover systems, the predicted average erosion rates for the landforms L4 and L5 was the lower than the linear slope. Landforms L8 and L9 demonstrated higher erosion rates than the straight slope landform especially along the areas where higher surface water flow concentrations were predicted. Cover system $5 \mathrm{~A}$ predicted to have the lowest erosion rates of all the different modelled landforms. This indicates that providing a filter layer along the flow concentration areas for landforms $L 8$ and $L 9$ can result in significant reduction in the average long-term erosion rates. That said, all erosion rates for $L 1, L 4$ and $L 5$ are all quite low and unlikely to result is significant rill erosion. The Geofluv ${ }^{\mathrm{TM}}$ designs (L8 and L9) are more prone to erosion especially along the flow concentration areas (drainages) and are likely to result in rill erosion when Plot $2 / 2 \mathrm{~A}, 3 \mathrm{~A}$ and 6 covers are used.

\section{Conclusion}

The proposed iterative workflow of field erodibility trials, WEPP analysis, Civil-3D with GeoFluv and SIBERIA offers an effective methodology to develop site-specific erosion parameters and to evaluate different landform and cover designs. 
Application of rocky covers, rock amended Gila covers are predicted to reduce the long-term erosion potential of the run of borrow Gila materials, and can achieve rates similar to that predicted for the adjacent undisturbed land. Use of rock that is too large is predicted to result in increasing rates of erosion as the proportion of the surface that is impermeable is increasing and the number of rock/soil interface where water can preferentially infiltrate is reducing. There appears to be a rock size (100 $\mathrm{mm}$ is a reasonable value) above which the increased runoff will result in erosion rates that could cause unacceptably high erosion rates. Use of a filter layer under the rock armour layers are predicted to reduce erosion more than when only the rock armour is applied. However, the adoption of the more complex bedding layer system may not be necessary for the linear slopes considered since the rock armour covers can achieve similar erosion rates as the undisturbed land.

Based on SIBERIA simulation of different landforms, predicted long-term (100 year) erosion rates associated with convex-concave slopes was observed to be lower than equivalent straight slope landforms. The natural drainage design analogues demonstrated a higher long-term erosion rate along the flow concentration areas. The material characteristics of the cover system at these areas will be re-evaluated and amended in the subsequent stages of the design to come up with an effective design. A multi-level decision matrix that incorporates various factors such as capital cost, maintenance community impact, and environmental impacts are being developed to select an effective cover system and landform.

\section{References}

Braun, T, Howard, E \& Chesal, T 2018, 'Planning closure of Arizona Closed Sites using field erodibility studies and erosion modelling', 2nd International Congress on Planning for Closure of Mining Operations, GECAMIN, Santiago.

Browning, G, Parish, CL \& Glass, JA 1947, 'A method for determining the use and imitation of rotation and conservation practices in control of soil erosion in lowa', Soil Science Society of America Proceedings, vol. 23, pp. 246-249.

Flanagan, DC \& Livingston, SJ 1995, 'WEPP User Summary', NSERL Report No. 11, National Soil Erosion Research Laboratory, West Lafayette.

Hancock, G, Loughran, R, Evans, K \& Balog, R 2008, 'Estimation of soil erosion using field and modelling approaches in an undisturbed Arnhem Land catchment, Northern Territory, Australia', Geographical Research, vol. 46, no. 3, pp. 333-349.

Howard, EJ 2018, 'Integrating erosion prediction into landform designs for rehabilitation and closure planning', Proceedings of the 2nd International Congress on Planning for Closure of Mining Operations, GECAMIN, Santiago.

Howard, EJ, Loch, RJ \& Vacher, CA 2013, 'Evolution of landform design concepts', Mining Technology, vol. 120, no. 2, pp. $112-117$.

Klingebiel, AA 1961, 'Soil factor and soil loss tolerance', Soil Loss Prediction, North and South Dakota, Nebraska, and Kansas, USDA-SCS.

Loch, RJ \& Donnollan, TE 1983, 'Field rainfall simulator studies on two clay soils of the Darling Downs, Queensland. I. The effects of plot length and tillage orientation on erosion processes and runoff and erosion rates', Australian Journal of Soil Research, vol. 21, pp. 33-46.

Loch, RJ, Robotham, BG, Zeller, L, Masterman, N, Orange, DN, Bridge, BJ, Sheridan, G \& Bourke, JJ 2001, 'A multi-purpose rainfall simulator for field infiltration and erosion studies', Australian Journal of Soil Research, vol. 39, pp. 599-610.

McCormack, DE, Young, KK \& Kimberlin, LW 1982, 'Current criteria for developing soil loss tolerance', in Determinants of Soil Loss Tolerance, American Society of Agronomy (ASA) Publication 45, pp. 95-112.

Priyashantha, S, Ayres, B, O'Kane, M \& Fawcett, M 2009, 'Assessment of concave and linear hillslopes for post-mining landscapes', Proceedings of the 8th International Conference on Acid Rock Drainage (ICARD) and Securing the Future: Mining, Metals \& the Environment in a Sustainable Society 2009, Swedish Association of Mines, Mineral and Metal Producers, Stockholm.

Renard, KG, Foster, GR, Weesies, GA, McCool, DK \& Yoder, DC 1993, 'Predicting soil erosion by water: a guide to conservation planning with the revised universal soil loss equation (RUSLE)', US Department of Agriculture, Handbook No. 703, Springfield, Virginia.

United States Department of Agriculture (USDA) 1981, Soil and Water Resources Conservation Act 1980 Appraisal Part 1, Soil, water, and related resources in the United States, Status, condition, and trends, viewed 20 March 2019, https://babel.hathitrust.org/cgi/pt?id=umn.31951d02881449s;view=1up;seq=1

US Department of Agriculture (USDA) Natural Resources Conservation Service (NRCS) 1999, National Soil Survey Handbook, Title 430-VI, US Government printing office, Washington DC.

US Department of the Interior Bureau of Reclamation 2014, 'Design Standard No.13 Embankment Dams', Chapter 7, Riprap Slope Protection Phase 4 (Final).

Willgoose, G \& Riley, S 1998, 'The long-term stability of engineered landforms of the Ranger Uranium Mine, Northern Territory, Australia: application of a catchment evolution model', Earth Surface Processes and Landforms, vol. 23, pp. 237-259. 
